\title{
Physico-chemical Characterization and Comparative Studies of Some Heavy Metals Using Activated Carbon from Date Palm Seed
}

\author{
Useh Mercy Uwem ${ }^{1,}$, Danlami Uzama ${ }^{1}$, Okonkwo Tochukwu Perpetua ${ }^{2}$ \\ ${ }^{1}$ Chemistry Advanced Research Centre, Sheda Science and Technology Complex, Kwali, Abuja, Nigeria \\ ${ }^{2}$ Chemistry Department, IBB University, Lapai, Nigeria
}

Email address:

usehmercy@gmail.com (U. M. Uwem)

${ }^{*}$ Corresponding author

\section{To cite this article:}

Useh Mercy Uwem, Danlami Uzama, Okonkwo Tochukwu Perpetua. Physico-chemical Characterization and Comparative Studies of Some Heavy Metals Using Activated Carbon from Date Palm Seed. Advances in Applied Sciences. Vol. 2, No. 4, 2017, pp. 54-59. doi: $10.11648 /$ j.aas.20170204.13

Received: October 4, 2016; Accepted: June 27, 2017; Published: August 1, 2017

\begin{abstract}
Activated carbon from date palm seed was analyzed to ascertain the physicochemical parameters and conduct comparative studies [with industrial activated carbons- Powdered Activated Carbon (PAC) and Granular Activated Carbon $(\mathrm{GAC})$ ] of some heavy metals $(\mathrm{Cd}, \mathrm{Pb}, \mathrm{Co}, \mathrm{Mn}$ and $\mathrm{Cr}$ ) present using standard analytical techniques. The physicochemical parameters of the activated carbon as determined were: Bulk density $(0.69 \mathrm{~g} / \mathrm{ml})$, Ash content $(6.92 \%)$, Iodine value $(10.38$ $\mathrm{mg} / \mathrm{g}$ ), Volatile organic matter (7.63\%), $\mathrm{pH}(6.92)$ and Moisture content $(0.60 \%)$. The result also showed that date palm seed activated carbon adsorbed more of the $\mathrm{Pb}$, as well as $\mathrm{Cr}$ better than the industrial activated carbon (GAC and PAC). The XRD result showed that the carbon has an amorphous structure which agrees with diffractogram of other activated carbons.
\end{abstract}

Keywords: Activated Carbon, Date Palm Seed, Physicochemical Parameters, Heavy Metals, Muffle Furnace, Iodine Value

\section{Introduction}

Activated carbon is broadly defined to include a wide range of amorphous carbon based materials prepared in such a way that they exhibit a high degree of porosity and an extended surface area in which impurities are trapped in the internal pore structure [1]. Moreover, all non-carbon impurities are removed and the surface is oxidized. Although today the term 'activated carbon' is taken for granted, a long time elapsed before it became generally adopted. The earliest known use of carbon in the form of wood chars (charcoal) by the Egyptians and Sumerians was in 3750 BC [2]. At that time, charcoal was used for various purposes such as reduction of ores in the manufacture of bronze, domestic smokeless fuel, and medicinal applications [3].

Nowadays, activated carbon finds wide application in many areas, but especially in the environmental field. Aside from environmental pollution control, it is mainly used in industry in various liquid and gas phase adsorptions [4]. Among liquid phase applications one can list food processing, preparation of alcoholic beverages, decolorization of oils and fats, product purification in sugar refining, purification of chemicals (acids, amines, gylcerin, glycol, etc.), enzyme purification, decaffeination of coffee, gold recovery, refining of liquid fuels, purification in electroplating operations, purification in the clothing, textile, personal care, cosmetics, and pharmaceutical industries, and applications in the chemical and petrochemical industries. Gas phase applications include recovery of organic solvents, removal of sulfur-containing toxic components from exhaust gases and recovery of sulfur, biogas purification, use in gas masks, among others. Activated carbon is also used in medical and veterinary applications, soil improvement, removal of pesticide residues, and nuclear and vacuum technologies. [5].

Today, activated carbon is very often utilized in the removal of various organic and inorganic species from surface water, groundwater, and wastewater. Raw waters taken from surface and groundwater supplies contain many organic compounds such as phenols, pesticides, herbicides, aliphatic and aromatic hydrocarbons and their chlorinated 
counterparts, dyes, surfactants, organic sulfur compounds, ethers, amines, nitro compounds, and newly emerging substances such as Endocrine Disrupting Compounds (EDCs). More than 800 specific organic and inorganic chemicals have been identified in various drinking waters, and many more are suspected to be present. Therefore, concerns are frequently expressed about the presence of these compounds, which can be present at levels as low as ng $\mathrm{L}_{-} 1$ or mg L $\_$. Because of their proven or suspected health and environmental effects, great efforts are made to control and/or remove them, and one of the major methods of doing this is by adsorption onto activated carbon [6].

In this study, the activated carbon was produced from Phoenix dactylifera commonly known as Date palm seed.

It is an interesting material with a good carbonaceous potential which constitutes approximately $10 \%$ of the fruit and has a small cylindrical embryo embedded in a sizable horny endosperm of cellulose. In spite of its high fiber content, date seeds are still considered as a by-product and are usually thrown away after consuming the flesh of the dates. With a world date production estimated at 7.6 million tons in 2015, 755 thousand tons of date seeds are approximately produced and can be used as an alternative source of activated carbon [7]. This agricultural byproduct has little economic value. Conversion of this agricultural byproduct into carbonaceous adsorbent that can be used in waste water treatment etc. would add to its value and help to reduce the cost of waste disposal and provide potentially cheap alternative to existing commercial activated carbon.

\section{Materials and Method}

\subsection{Adsorbent Preparation}

Date palm seed was purchased from Lapai market in Niger State. It was washed and dried in an oven at $105^{\circ} \mathrm{C}$ for 24 hours to remove moisture. $317 \mathrm{~g}$ of the seed was weighed and carbonized in a muffle furnace at $450^{\circ} \mathrm{C}$ for 2 hours and was allowed to cool at room temperature. The char was grounded into fine powder and poured into $20 \%$ phosphoric acid, it was boiled for 1 hour and kept at room temperature for 24 hours. The char was filtered and dried in an oven at $105^{\circ} \mathrm{C}$ for 24 hours. The dried char was activated in a muffle furnace at $800^{\circ} \mathrm{C}$ for 10 minutes, the activated carbon was grounded and sieved using $300 \mu \mathrm{m}$ sieve and was washed with distilled water until the $\mathrm{pH}$ was 6.92 . The activated carbon was dried at $105^{\circ} \mathrm{C}$ in an oven and stored in an air tight container for further adsorption studies [7].

\subsection{Adsorbate Preparation}

Stock solutions of $1000 \mathrm{mg} / \mathrm{L}$ of metal ions were prepared by diluting with deionised water. All adsorption experiments were carried out using reagent bottles of $250 \mathrm{~mL}$ capacity containing different amounts of each adsorbent in $200 \mathrm{~mL}$ solutions of different concentrations. The $\mathrm{pH}$ of each experimental solution was adjusted to the required $\mathrm{pH}$ value using $1 \mathrm{~N} \mathrm{NaOH}$ before mixing the adsorbent.

\section{Physico-chemical Characterisation of the Activated Carbon}

Ash content and bulk density were carried out using a standard method by Ahmedna [7] while the moisture content, volatile organic matter and iodine value were determined as described by Nurul' Ain [8] and [9] respectively. For X-ray diffraction (XRD), the amorphous structure of the carbon was determined using PANalytical x-ray diffractometer.

\section{Results and Discussion}

Table 1 shows the physicochemical parameters of Date palm seed activated carbon. The value of the moisture content, $0.60 \%$ indicates a long shelf life and it is close to the moisture content of rice husk reported by Subhashree [10] as $0.4 \%$. The bulk density of the carbon is in close agreement with the values, $0.35-1.2 \mathrm{~g} / \mathrm{ml}$ reported for other agricultural material by Oyo \& Igbokwe [11] and Bensal [12].

Table 1. Physicochemical parameters of the Activated carbon.

\begin{tabular}{ll}
\hline PARAMETERS & VALUES \\
\hline Bulk density & $0.69 \mathrm{~g} / \mathrm{ml}$ \\
Ash content & $6.92 \%$ \\
Iodine value & $10.38 \mathrm{mg} / \mathrm{g}$ \\
Volatile organic matter & $7.63 \%$ \\
$\mathrm{pH}$ & 6.92 \\
Moisture content & $0.60 \%$ \\
\hline
\end{tabular}

The iodine value is close to the values reported by Rajeshwari [13] for activated carbon prepared from parthenium. The $\%$ yield was $20.5 \%$, the low yield could be due to the fact that significant amount of the carbon is lost from glucose derivatives due to volatilization and as a result, the char is low. Significant product yield can also be observed depending on the origin of the carbon material [14]. The $\mathrm{pH}$ of the solution affects the surface charge of the adsorbents as well as the degree of ionization and speciation of different pollutants [15]. It is known that metal species (M) are present in deionized water in the form of $\mathrm{M}^{2+}$, $\mathrm{M}(\mathrm{OH})_{2}$, and so on [16]. It is obvious that the adsorption of metal species must be higher in alkaline solution. But at higher $\mathrm{pH}$, the precipitation as $\mathrm{M}(\mathrm{OH})_{2}$ plays the main role in removing the metal ions. Therefore, all the experiments were conducted at $\mathrm{pH} \leq 8$. The working $\mathrm{pH}$ value was chosen to be 6.92 for both the date palm seed activated carbon and the industrial activated carbon (granular activated carbon and powdered activated carbon).

Fig. 1 represents the XRD Pattern for Date palm seed. This analysis was performed on date seeds powder. Samples were placed in a $2.5 \mathrm{~mm}$ deep cell and the measurements were performed with a PANalytical, X'Pert PRO MPD diffractometer (PANalytical, Massachusetts, USA) equipped with an X'celerator detector. The operating conditions for the refractometer were: copper $\mathrm{K} \alpha$ radiation (1.5418 $\AA$ ), $2 \theta$ (Bragg angle) between $5^{\circ}$ and $60^{\circ}$, step size of $0.067^{\circ}$ and counting time of $90 \mathrm{~s}$.

The d-spacings were calculated using the Bragg equation: 
$\mathrm{n} \lambda=2 \mathrm{~d} \sin \theta$

where $\mathrm{n}$ is the order of reflection, $\lambda$ is the wavelength of the incident $\mathrm{X}$-rays, $\mathrm{d}$ is the interplanar spacing of the crystal and $\theta$ is the angle of incidence.
The diffractogram of date seed does not exhibit a horizontal basic line. This shows that the major part of the matter is amorphous (Fig. 1).

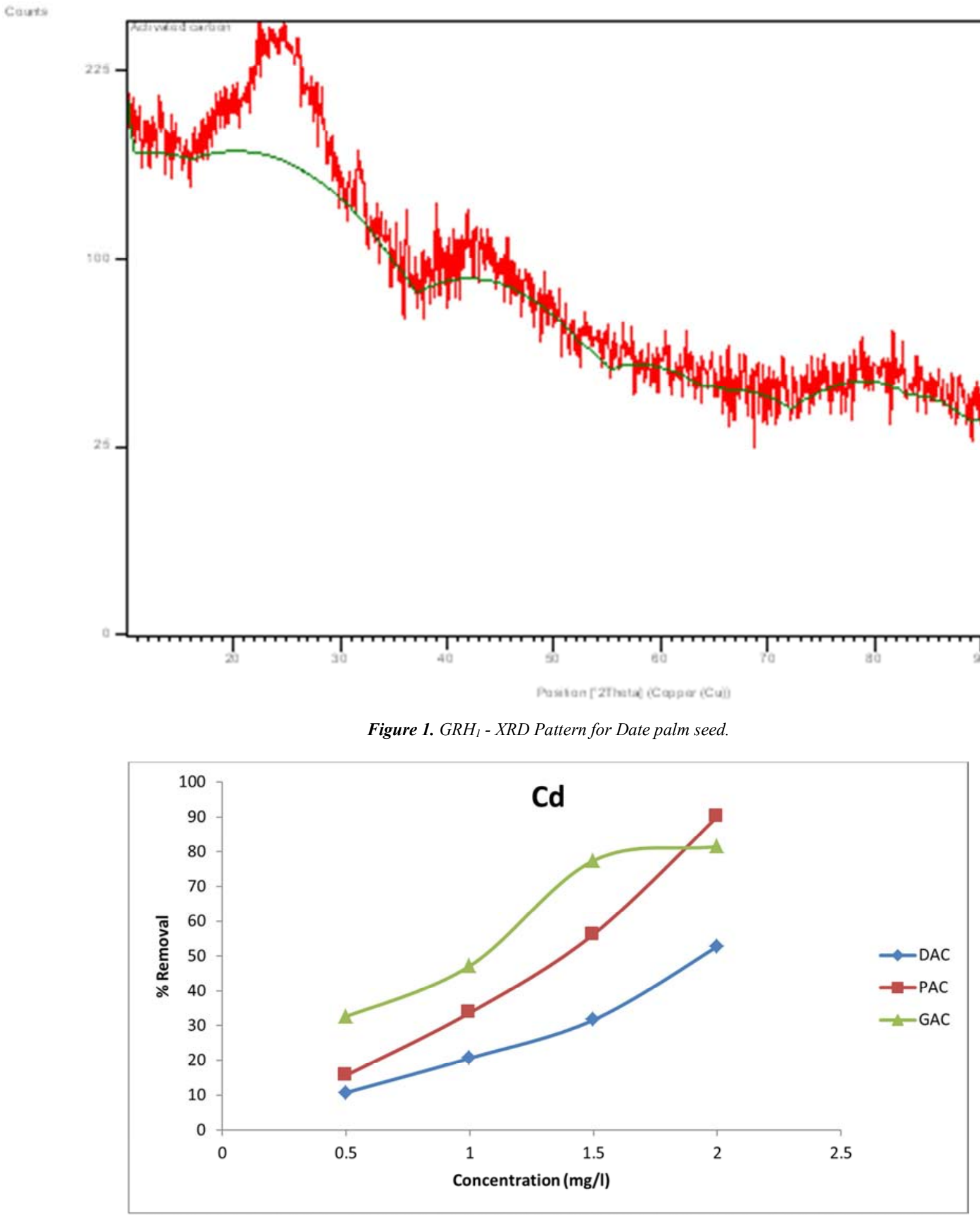

Key: Date Palm Activated Carbon (DAC). Powdered Activated Carbon (PAC). Granular Activated Carbon (GAC).

Figure 2. Effect of varying concentration on the comparison adsorption of Cadmium. 


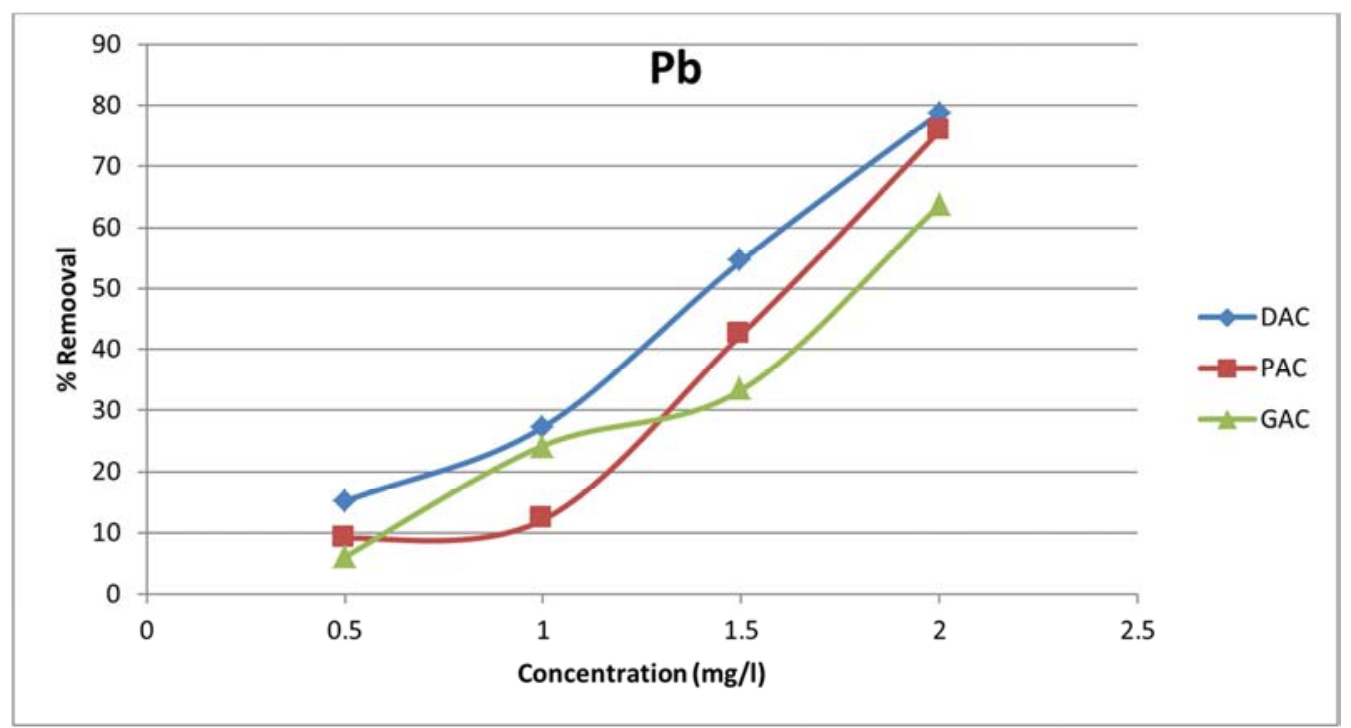

Figure 3. Effect of varying concentration on the comparison adsorption of Lead.

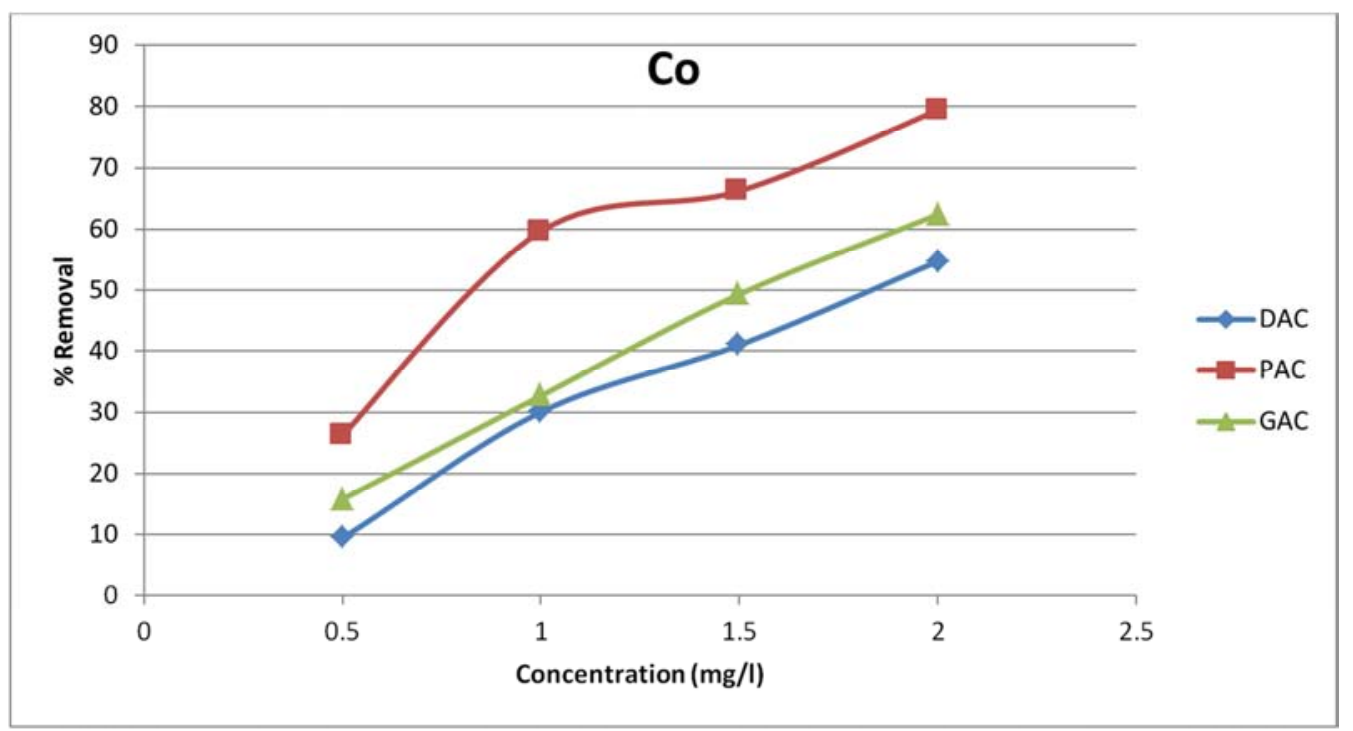

Figure 4. Effect of varying concentration on the comparison adsorption of Cobalt.

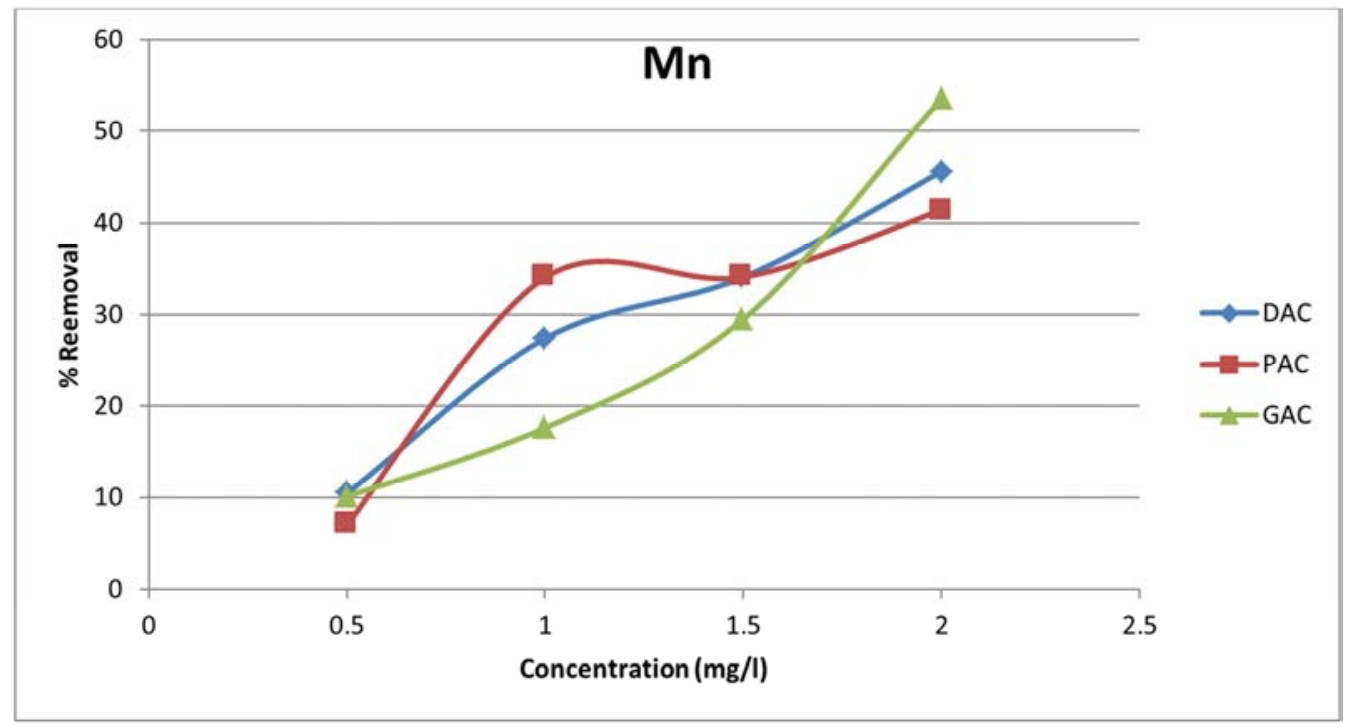

Figure 5. Effect of varying concentration on the comparison adsorption of Manganese. 


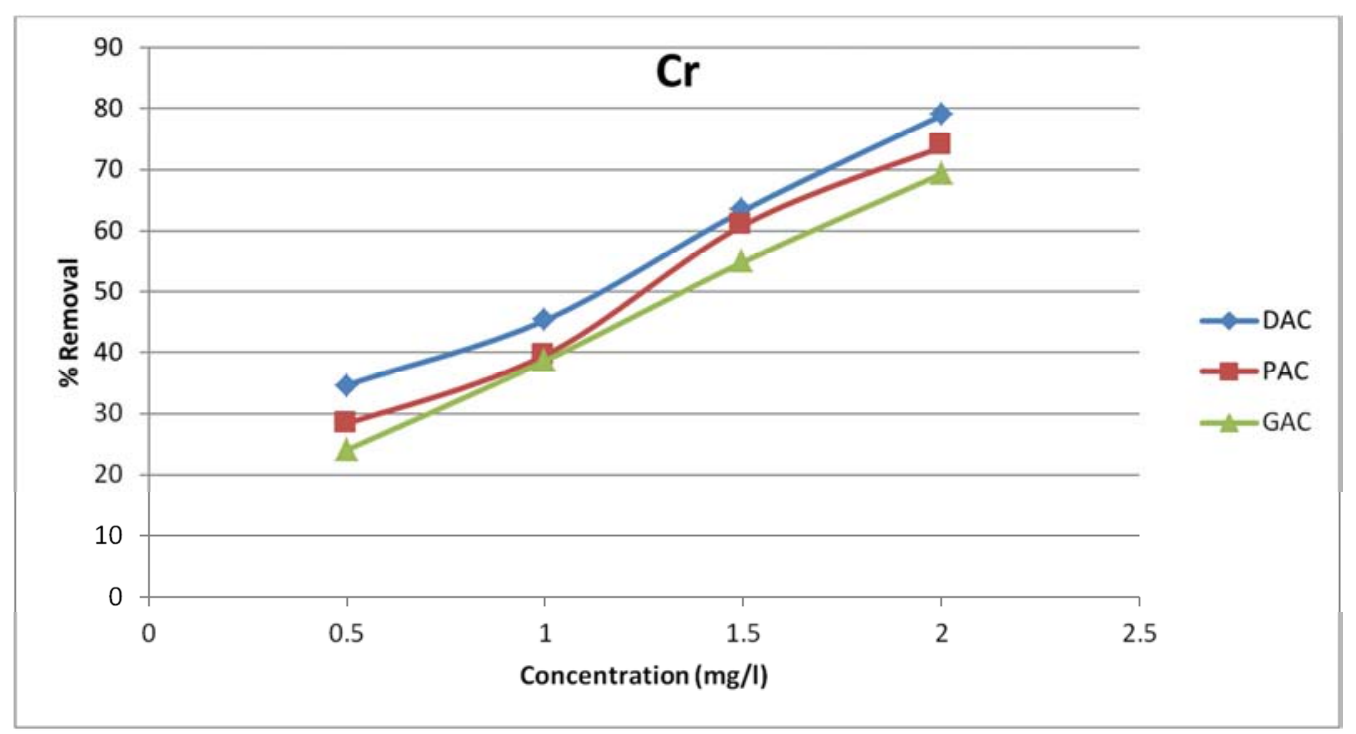

Figure 6. Effect of varying concentration on the comparison adsorption of Chromium

The adsorption experiments were carried out with metal ions $(\mathrm{Cd}, \mathrm{Pb}, \mathrm{Co}, \mathrm{Mn}$ and $\mathrm{Cr})$ concentrations of $0.5,1.0,1.5$ and $2.0 \mathrm{mg} / \mathrm{L}$ with a constant amount of $0.5 \mathrm{~g}$ at a $\mathrm{pH}$ of 6.92 for all the activated carbons. The amount adsorbed per unit mass of each metal at different concentrations is shown in Figures 2 to 6 . There are various possible interaction effects between different species in solution and, in particular, potential interactions on the surface depending on the adsorption mechanism. In the context of adsorption, a number of properties have been suggested for use in the ordering of affinity rank, including ionic radius, solubility product constant, electronegativity and standard reduction potential [17]. These properties may play an important role in metal ion adsorbent interaction, but can only partly explain high- or low-adsorption capacities.

From fig. 2 above, the industrial activated carbon (GAC and PAC) showed higher adsorption capacity for $\mathrm{Cd}$ as compared to date palm seed activated carbon. But looking at fig. 3 and fig. 6, date palm seed activated carbon adsorb more of the $\mathrm{Pb}$, as well as $\mathrm{Cr}$ better than the industrial activated carbon (GAC and PAC).This could be as a result of high affinity for the metal ions and high molecular weight of compound used. The XRD result showed that the carbon has an amorphous structure which agrees with diffractogram of other activated carbons. Date palm being one of the major biomass sources, largely being cultivated in Nigeria, has been proven for its potential to be an appropriate cheap, locally available and non-toxic precursor for preparation of porous carbon.

\section{Conclusion}

Preparation of activated carbon from date palm seed was carried out successfully. The various properties studied in this research work indicated the applicability of date palm seed as an effective low cost adsorbent for removal of some heavy metals.

\section{Recommendation}

Further work can be done on the FT-IR and SEM which gives information about the functional group and the morphology of the activated carbon which may give an insight on the better adsorption of $\mathrm{Pb}$ and $\mathrm{Cr}$ amongst other heavy metal used.

\section{References}

[1] Hassler, J. W. (2010) Activated Carbon, Chemical Publishing Co., Inc., New York, N. Y., USA.

[2] Dabrowski, A. (1998) Adsorption - its development and application for practical purposes, in Adsorption and Its Applications in Industry and Environmental Protection. Studies in Surface Science and Catalysis, vol. 120 (ed. A. Dabrowski), Elsevier Science B. V., pp. 3-68.

[3] Bansal, R. P. and Goyal, M. (2005) Activated Carbon Adsorption, CRC Press, Taylor \& Francis Group, 6000 Broken Sound Parkway NW, Suite 300 Boca Raton, FL, USA 33487-2742.

[4] Purcell, P. J. (2006) Milestones in the development of municipal water treatment science and technology in the 19th and early 20th centuries: part I. Water and Environment Journal, 19 (3), 230-237.

[5] Hung, Y. T., Lo, H. H., Wang, L. K., Taricska, J. R., and Li, K. H. (2005) Granular activated carbon adsorption, in Physicochemical Treatment Processes, Handbook of Environmental Engineering, vol. 3 (eds L. K. Wang, Y. T. Hung and N. Shammas), Humana Press Inc., Totowa, New Jersey, USA pp. 573-633.

[6] Hendricks, D. (2006) Water Treatment Unit Processes: Physical and Chemical, CRC Press. Printed in the USA.

[7] Ahmedna, M. M. Johns, M. H. Clarke, S. J. Marshall, W. E. and Rao, R. M. (1997). J. Sci. Food Agric., 75,117-124. 
[8] Nurul'Ain. Bint. Jabit. (2007). The production and characterization of activated carbon using Local Agricultural waste through Chemical Activation process, p.p 10- 40.

[9] ASTM (2002). Activated Carbon Standards. American Society for Testing and Materials. Online. Fritz publication. Http: // www.fritz.com.

[10] Oyo, K. B, Igbokwe, P. K. (2001). Production of activated carbon from coconut shell. J. Chem. Soc. Nig. 26 (1); 91-94.

[11] Subhashree P. U. (2011). Production and characterization of activated carbon produced from a suitable sludge (research project) p.p 12-13.

[12] Bensal C. B. Donnet J. B. and Stoeckli, F. H. (2012). Active Carbon, New York: Marcel Dekker. Pp.23-45.
[13] Rajeshwari, Siva raj and Rajendran, Venckatesh. (2010). EJournal of chemistry, 7 (4), 1314- 1319.

[14] Guo J. Lua A. C. (2009): Characterization of adsorbents prepared from oil palm shell by thermal activation for removal of gaseous pollutants. Material Sci. 55: 334 -339.

[15] Kandah M. I., (2011). "Zinc and cadmium adsorption on lowgrade phosphate," Separation and Purification Technology, vol. 35, no. 1, pp. 61-70.

[16] Ansal R. C. and M. Goyal, (2009) Activated Carbon Adsorption, Taylor \& Francis, London, UK.

[17] Brown, P. A. Gill, S. A and S. J. Allen (2012). "Metal removal from wastewater using peat," Water Research, vol. 34 , no. 16, pp. 3907-3916. 